\title{
Flints from the Road: on the Significance of two Enigmatic Stone Tools Found along the Darb el-Tawil
}

\author{
Heiko Riemer ${ }^{a}$ and Karin Kindermann ${ }^{b}$
}

\begin{abstract}
This paper explores the function and dating of two rectangular flint tools found at different positions along the Darb el-Tawil caravan route. This route directly connecting the Dakhla Oasis with the Nile Valley has seen caravan transport during almost 4500 years from the Old Kingdom to the 2oth century. The two flint objects are a rarity along this route but are also not well-known from archaeological sites elsewhere in Egypt. In bringing together the evidence from the site contexts of the current flint tools with parallels related to morphology and technical aspects of types of flint tools known from Egypt or beyond, it is concluded that these artefacts are likely to be interpreted as a sickle element in the one case and a gunflint in the other.
\end{abstract}

KEY-WORDS: Egypt, caravan route, sickle element, gunflint

\section{INTRODUCTION}

The current paper seeks exploring the functional significance and cultural background of two enigmatic flint tools found during the survey along the Darb el-Tawil caravan route. The Darb el-Tawil is the principle route directly connecting Dakhla Oasis with the Nile Valley. Its primary track starts from the old town of Balat in the eastern part of this oasis, and enters the Nile Valley at Beni Adi in the area of Manfalut after some $250 \mathrm{~km}$ (Fig. I).

Since the beginning of road construction in 2015 of a modern asphalt highway planned to follow exactly the tracks of the caravan route, investigations have started to survey the old route and document its sites and artefacts (Bubenzer et al., 20I8). Due

a University of Cologne, Institute of Prehistoric Archaeology, African Archaeology, Jennerstraße 8, 50823 Köln, Germany; e-mail: heiko.riemer@uni-koeln.de; ORCID: 0000-0002-2251-3734

$b$ University of Cologne, Institute of Prehistoric Archaeology, African Archaeology, Bernhard-FeilchenfeldStraße II, 50969 Köln, Germany; e-mail k.kindermann@uni-koeln.de; ORCID: 0000-0003-0311-6319 


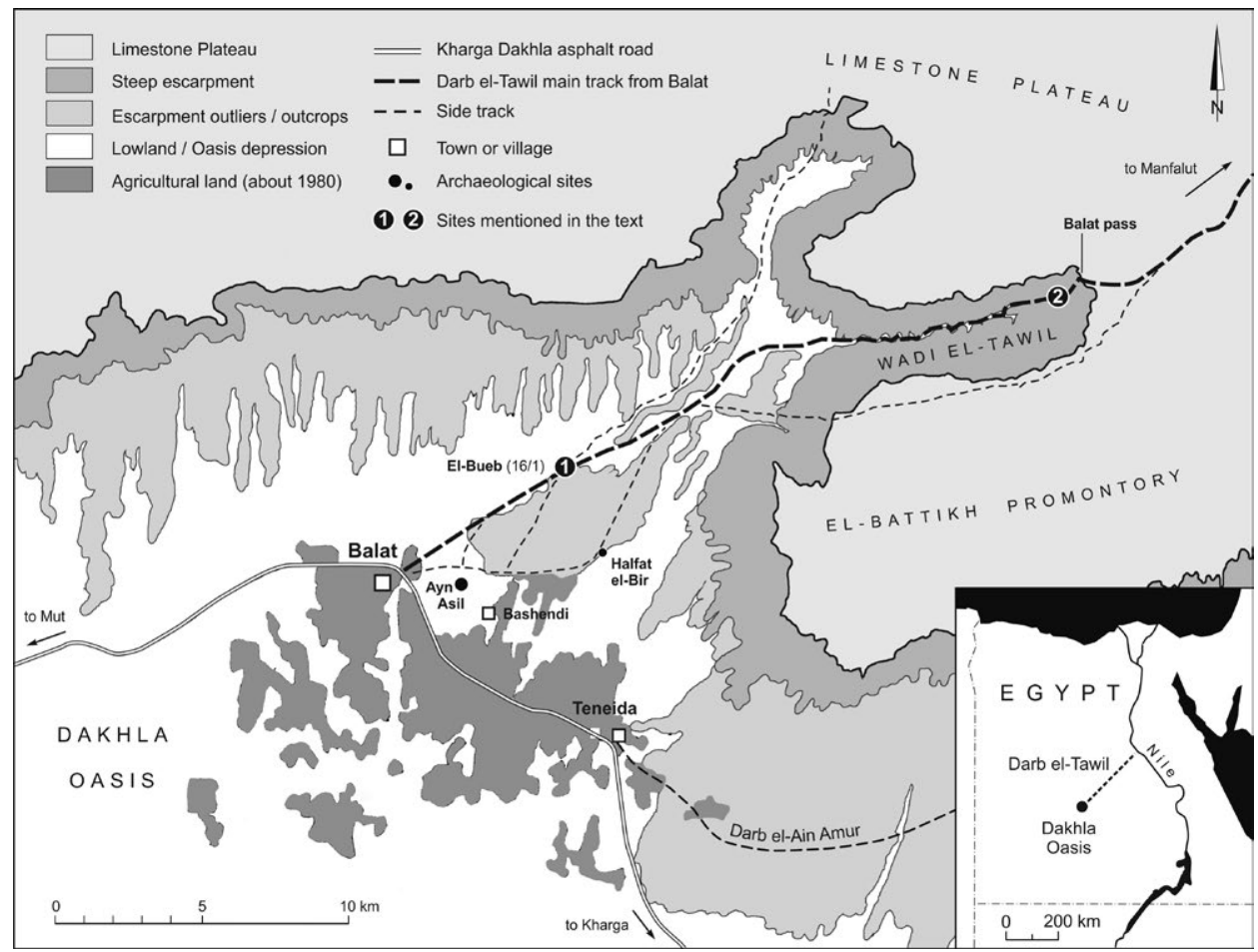

Fig. I. Map of the eastern part of the Dakhla Oasis showing the positions of the two flint objects found along the Darb el-Tawil caravan route: $\mathrm{I}$ - Sickle insert; 2 - Gunflint.

Graphic design: H. Riemer.

to administrative reasons, only about the first $30 \mathrm{~km}$ from Balat leading up to the socalled Balat pass, where the road finally enters the Egyptian Limestone Plateau, have been surveyed. It was on this stretch of road that the two flint tools were found (Fig. 2).

Pottery makes up the most numerous category of artefacts found along this route. Sherds of about Iooo ceramic vessels allowed the first comprehensive chronological sequence of this route to be established. It shows that the Darb el-Tawil was firmly established already during the Old Kingdom, as previously supposed in earlier papers on the basis of the rich Old Kingdom remains excavated at Dakhla Oasis (e.g., Giddy 1987: 208). Caravan transport along this route lasted for more than 4000 years until the 2oth century, when it ceased during the I970s. A few phases are not properly represented in the corpus of pottery from this route, especially the Middle and New Kingdom material. The absence of material from the latter periods is likely a result of a shift of state-organized transport to more westerly routes, when the capital moved from Memphis to Upper Egypt. Knowledge of pottery of Islamic times in Egypt has 

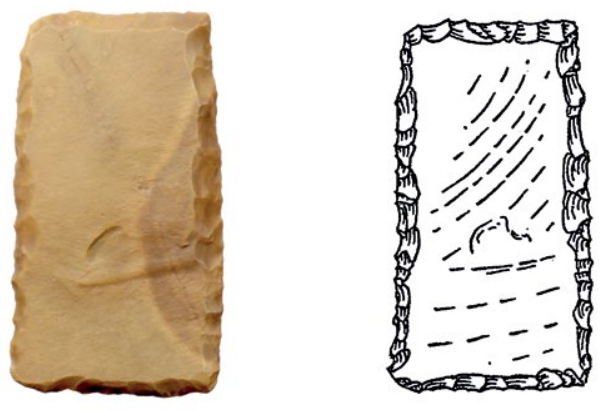

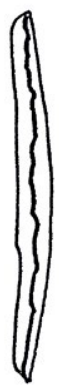

1

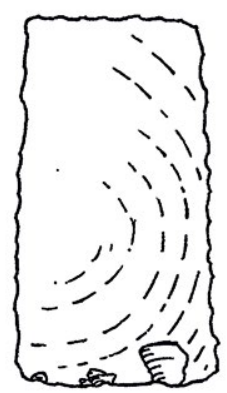

ID 161104

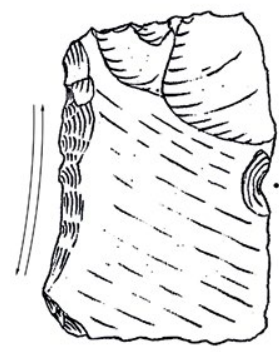

ID 172351

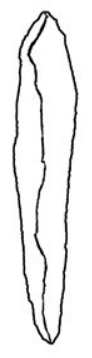

2
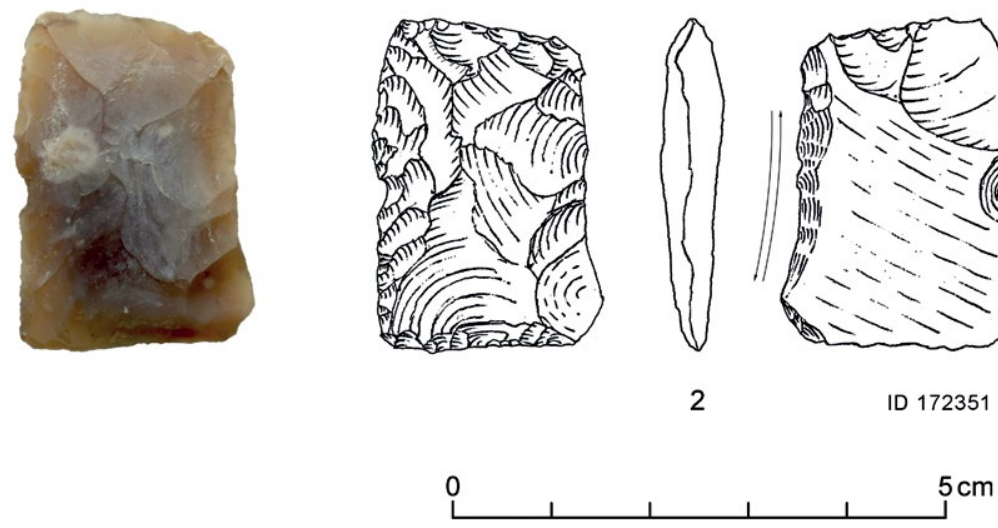

Fig. 2. Two chipped flint objects from the Darb el-Tawil caravan route:

I - Suggested rectangular sickle element from site El-Bueb 16/1; 2 - Suggested gunflint from the environs of the Balat pass. Scale i:I. Computer graphics: H. Riemer and K. Kindermann.

only tremendously improved recently, however, it is still not well understood regarding regional variations; and Ottoman ceramics are even less well studied. Yet, there are many ceramic and other objects from these phases along the Darb el-Tawil indicating intense caravan transport there.

The flint finds that are the subject of the present paper were associated with this caravan route. The period when this route was in operation sets the time frame for the dating of these flint objects. In the following it is attempted first to discuss the problems and possibilities of dating of artefacts found along a caravan route. In a second step, it is attempted to apply these rules to both flint objects individually in order to establish a best-fit statement on their dating and function. 


\section{METHODS: DATING AND CONTEXT OF STONE ARTEFACTS ALONG A CARAVAN ROUTE}

The assigning of artefacts found along a caravan route to specific periods of time is particularly difficult due to a number of reasons. Due to the highly mobile character of human activities along desert routes, most objects found there are single surface finds or related to shallow deposits, meaning that the contextual information is extremely meagre or even non-existent. Most of the objects found on the route were accidentally lost during its use, for example as the result of a mishap involving a pack animal or loss of a load due to improper lashing. The few places where caravans halted for a rest are often littered with artefacts; but again most objects found there result from the accident-prone moments of loading and unloading when the pack animals are agitated. Some objects, however, could have been deliberately placed at these places, such a storage jar in a water depot or a cooking pot next to the camp fire, but these deposits are usually shallow and do not provide much contextual information.

Objects found without context may be dated by comparison with types well dated elsewhere. Much of the pottery found along caravan routes has been identified in this way. It is, however, fair to say that in every region some phases in the chronological sequence are usually less well known than others. This is particularly true for the most recent phases in Egypt, such as the late Medieval and Ottoman periods. Moreover, some pottery represents types especially used for caravan transport or storage, which rarely shows up as stratified finds in excavations of settlements, temples or burials.

The interpretation of single stone artefacts in this regard is even more difficult. Stone tools of some periods are not characteristic enough for single artefacts to be ascribed a date. This especially pertains to the expedient production of some late prehistoric groups, such as the Sheikh Muftah in the Dakhla Oasis. The present almost total lack of knowledge of post-Old Kingdom stone knapping traditions in Egypt is another reason that dramatically hampers proper identification of loose stone tools found along a caravan route.

As far as we can see, regular trade and transport along caravan routes was only established in the socio-economic-context of early state formation, when geopolitical, economic and social preconditions substantially increased the demands for transportation and exchange of resources and products. Potentially, this would exclude the dating of objects to earlier periods; but unfortunately it is largely unknown when exactly most roads were established.

It should, however, also be noted that roads usually did not develop out of nothing; rather it appears that some roads were established on older trail networks of local nomadic people, as seems to be the situation in the case of the Darb el-Tawil. It cannot be excluded that artefacts found on a caravan route originally came from a site that predates the establishment of the route. The oasis depression of Dakhla is rich 
Flints from the Road: on the Significance of two Enigmatic Stone Tools Found along the Darb el-Tawil $\mid$ 26I

in archaeological remains of prehistoric camp sites, the artefacts of which often have survived on the desert surface due to excessive wind erosion and low sedimentation rates. This also holds true for many prehistoric camp sites by short-term water basins on the Egyptian Limestone Plateau between this oasis and the Nile Valley. It is not surprising that caravan tracks accidentally crossed abundant prehistoric sites from which stone artefacts in particular have survived.

In the following discussion, the two objects in question will be interpreted first in the frame of their individual find positions along the caravan route and the evidence that their respective spatial contexts at these locations provides. Secondly, we will seek possible parallels known from Egyptian contexts, and in the case that no parallel can be found from these sources, to search on a global scale.

\section{SICKLE ELEMENT (OBJECT ID 161104), ABOUT 7 KM FROM BALAT AT SITE EL-BUEB 16/1}

\section{Location and context}

The flint item in question here is a rectangular retouched flint tool made of a thermoclastic sherd of so-called "caramel flint" (Fig. 2:I). This flint artefact was found associated with one of the most productive activity sites discovered during the Darb el-Tawil survey so far. This site, situated about $7 \mathrm{~km}$ from the old town of Balat in the eastern oasis (Fig. I), is the most prominent natural landmark along the principle track of the Darb el-Tawil half-way between Balat and the mouth of the Wadi el-Tawil. It features in the landscape as a conspicuous sandstone ridge in an otherwise rather featureless landscape, with the route winding through a cut in the ridge downwards into an old playa pan. In the survey, this place was labelled site $16 / 1$, but is known locally to old caravanmen as El-Bueb, "the small gate or door" (cf. Moritz 1900).

Archaeological inspection of this site revealed a high density of potsherds, bones, stone artefacts and other indications of repeated human activity related to caravan transport. The site is not only prominent from its natural appearance, but a number of artificial features of practical and symbolic functions. Numerous alamat (cairns) on the tops of the flanking rocks as well as rock engravings signal a site of importance. The latter feature Arabic names of the 19th and 2oth century, some with dates added. On the other end of the time scale, there are a few pharaonic engravings in a rock shelter, accompanied by some sherds of red-slipped bowls of Old Kingdom/First Intermediate Period age. The shelter is some $5 \mathrm{~m}$ above the ground, but well-protected from the wind and with a good view of inbound caravans. There is also a windscreen on top of the site's front rock providing a commanding panoramic view, indicating that this is one of the so-called "hilltop sites" interpreted as serving to control caravan routes during the Old Kingdom (Kaper and Willems 200o). It is therefore likely that this site 
was manned permanently or during longer periods in the caravan season. The site is within the distance of a one-hour normal march from Ayn Asil, the provincial capital of Dakhla Oasis during the late Old Kingdom/First Intermediate Period (or about half of the time for a running messenger).

Stone artefacts found directly on the tracks of the caravan route were not collected, because the danger of pseudo-flaking on flint pieces or older blank products resulting from trampling by pack-animals is so high that we presume that $100 \%$ of the flint pieces there would be affected by this process (cf. Driscoll et al., 2016). The site's surfaces away from the tracks, however, have been surveyed carefully for retouched items. There is a very low-density scatter of stone artefacts over most of the site. One scatter in front of the aforementioned habitation shelter is of higher density, and especially composed of some ready-made tools. They represent end- or laterally edge-retouched items and borers. The overall impression is that of an expedient blank production characterized by informal flakes and naturally formed flint pieces (thermo-clastic pieces). This way of production is typical for the expedient "outdoor" production at some hill-top sites around Dakhla Oasis as well as for the local nomadic Sheikh Muftah people (cf. McDonald 2000; Riemer 20II; Kobusiewicz 20I5).

Most of the items are made of omnipresent Palaeocene Tarawan sherd available sub-locally from outcrops in the escarpment cap rock, and locally in the debris on escarpment outliers ranging for some kilometres into the depression of the oasis (Kleindienst et al., 1999: 89). The conspicuous caramel flint, obviously occurring in the upper beds of the same geological formation, is represented only twice at the site, pointing to the use of resources that are more exotic. Outcrops of this material have been found atop the escarpments of Kharga Oasis. Farther west, along the rim of the Abu Gerara escarpment, prehistoric sites contain the highest percentage of this good-quality raw material that appears in different qualities and shape there, mainly in tabular blocks and as thermo-clastic sherds on the surface (Kindermann 20IO). According to the these observations, the position of the sources providing caramel flint were about $100 \mathrm{~km}$ away from Balat, but can easily be accessed from Balat via the Darb el-Tawil within three marching days.

\section{Rectangular sickle elements in the Dakhla Oasis}

The stone tool of interest is a rectangular flat piece of caramel flint with all four edges regularly retouched by semi-steep flaking. This rectangular object from site 16/1 parallels pieces found in great numbers in the context of the Old Kingdom / First Intermediate Period settlements of Dakhla Oasis. Due to the finding of sickle gloss on their lateral edges, they are interpreted as insets in wooden sickle shafts, of which a reconstruction is shown by Jeuthe (2012: I42; cf. Kobusiewicz 2015: 76). In archaeological contexts, rectangular sickle elements are usually accompanied by triangular elements, the latter forming the end-pieces in a series of rectangular elements fitted into the sickle shaft (Fig. 3:2). 

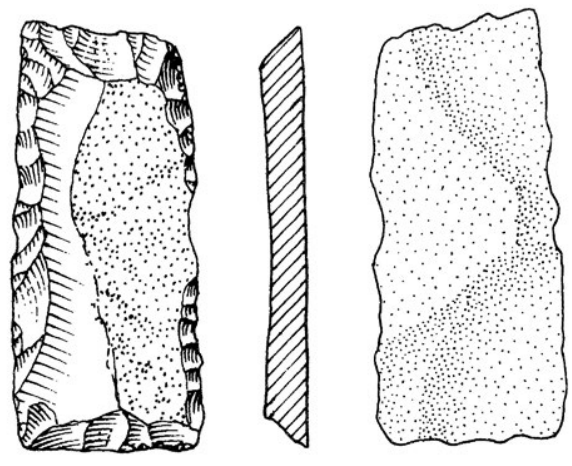

1

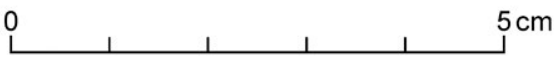

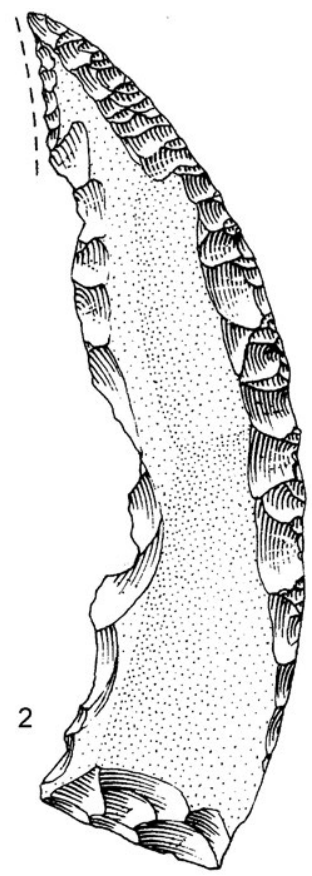

Fig. 3. Old Kingdom/First Intermediate Period flints from Ayn Asil, Dakhla Oasis: I - Rectangular sickle element (with gloss); 2 - Triangular sickle element (modified after Midant-Reynes 1998: pl. 23.2; 25.I). Drawn: H. Riemer.

Both rectangular and triangular examples of these insets from the oasis are usually not made of blades or flakes chipped from a core, but of tabular thermo-clastic sherds, the latter which usually form natural debris piles at flint outcrops on the Limestone Plateau from where they probably originate. They differ markedly from sickle elements made out of regular blades, which occur in great numbers in other Predynastic to Old Kingdom contexts in Egypt. The alternative use of tabular thermo-clastic material is obviously a phenomenon characteristic for the southern oases of the Western Desert, where lithic tools for agricultural purposes were introduced not before the colonization of Dakhla Oasis by Pharaonic Egypt presumably during the 3rd to 4th dynasty (Hope and Pettman 20I2).

Midant-Reynes, in her analysis of the lithic material from Ayn Asil, explicitly distinguishes between (I) regular blades or segments of blades exhibiting sickle gloss and (2) rectangular or triangular sickle elements of tabular flint with gloss on, "imitating" blades or blade segments of the same function (Midant-Reynes 1998: 31; Fig. 3). This approach was further developed by Jeuthe in her study of the lithic workshops from the same site (Jeuthe 20I2: 135). Kobusiewicz, who studied the lithic collection from Ayn 
264 Heiko Riemer and Karin Kindermann

el-Gazzareen in the western part of Dakhla, names the above first type "sickle blade" as opposed to the second type, which he calls "massive rectangular/triangular sickle inserts" (Kobusiewicz 20I5: 34).

Ayn Asil and Ayn el-Gazzareen, at which sickle elements are abundant, are among Dakhla's main settlement centres during the Old Kingdom/First Intermediate Period. Both settlements are characterized as centres of trade and agricultural production. The crafts also include the production of sickles for the harvest and their lithic insets in workshops specialized in the standardized mass-production of this type of lithic elements, such as amply indicated in Jeuthe's study (20I2). Ayn Asil additionally represents the provincial capital of the oasis with the palace of the governor, and was probably the primary centre from which cultivation and transport of produce as well as exchange with the Nile Valley were administered. This given, it is not surprising that most sickle elements come from excavations of these settlements: I70 sickle insets from Ayn el-Gazareen represent about one fourth of all chipped lithic tools found at this site; and again about one fourth of the insets are on tabular thermo-clastic material (Kobusiewicz 2015: 34). The workshop assemblage from Ayn Asil numbers 1449 sickle insets or about half of all chipped lithic tools there; three-quarters of the insets are on tabular material (thermo-clastic pieces). Yet chipping from tabular material was by no means preferred as the production method of sickle insets: At Ayn el-Gazzareen, more than half of all tools were made of tabular material, about the double of the percentage of the tabular sickle insets. At Ayn Asil, the proportion of insets on tabular material is actually only slightly below the mean in the tool total, the latter at almost $80 \%$.

Despite all the similarities in the occurrence of sickle elements in the early settlements of Dakhla, there is also some variation apparent between Ayn el-Gazzareen and Ayn Asil in the frequencies of sickle elements and the respective raw materials, this may be because of a multitude of secondary factors difficult to pin down. The highest density of sickle elements in the lithic workshop area at Ayn Asil is self-explaining; but there might also be a distinction in the political significance between the two settlements, with Ayn el-Gazzareen probably subordinated to Ayn Asil in terms of administration. Moreover, the different geographic positions in the Dakhla depression, Ayn el-Gazzareen lying about $40 \mathrm{~km}$ west of Ayn Asil, may have facilitated different access to raw materials on the local and more distant level. Finally, it should not be forgotten that these settlements have varying chronological sequences with a range of overlap currently difficult to define precisely: Ayn el-Gazzareen and the lithic assemblage has been pottery-dated to dynasties 5 and 6 (Pettman 20I2; Kobusiewicz 20I5: 26). For Ayn Asil, the material studied by Midant-Reynes comes from contexts generally dated to the late Old Kingdom/First Intermediate Period (Midant-Reynes I998: I). The workshop area excavated by Jeuthe is associated to building phase 2 dating to the final Old Kingdom/First Intermediate Period (Jeuthe 20I2: 3I-37; Jeuthe et al., 2013). 
Few rectangular sickle insets came from sites other than the settlements. Their number is extremely small, and elements of this kind may represent accidental losses or items used opportunistically for other purposes. Only one exception deserves mentioning due to its special context. Valloggia (1986: pl. 87) presents a small collection of triangular and rectangular sickle elements found in the mastaba of the Governor Medu-Neferat at Qilla el-Debba, the burial ground of the local dignities of Ayn Asil.

Without any doubt, the present lithic tool found at site El-Bueb 16/1 represents a rectangular sickle element made on a tabular piece of caramel flint. This is likewise supported by the metrical values of this object, which fits into the figures given for such objects in the studies from Ayn Asil.

The data taken from the study by Midant-Reynes (1998: 3I) on the lengths and widths of rectangular elements are not directly comparable with those published by Jeuthe (2012: I40). While Midant-Reynes gives mean, maximum, minimum and standard deviation of length and width measurements of 87 rectangular elements, Jeuthe provides the number of elements by length and width classes. However, it is possible to extract approximate $68 \%$ (standard deviation) and $95 \%$ ranges from her data. It should however be noted that all 9 elements of Jeuthe's variant " 2.3 " have been excluded from the type of rectangular elements in the present analysis, because in our opinion they rather represent a variant of triangular shape (cf. Jeuthe 2012: 59), so that a total of I85 rectangular elements remain from Jeuthe's study. The graph in Fig. 4 shows that the specimen found at site El-Bueb 16/1 is a rather small representative of the category of rectangular elements. Nevertheless, with a length of $38 \mathrm{~mm}$ and a width of $2 \mathrm{I} \mathrm{mm}$, it is in the range of the standard deviations given for lengths and widths measurements by Midant-Reynes, and only marginally shorter than the standard deviation approximation of lengths measurements from the data given by Jeuthe.

It is notable that the rectangular sickle element from site El-Bueb 16/1 has no sickle gloss, either because it has never been used for cutting, or due its long surface exposure that is suspected of being destructive to gloss preservation. This also touches on the question of the significance of a sickle element left behind at a hill-top site of a caravan route. One possibility is that the sickle element had been brought from Dakhla by the men stationed at the hill-top site, in order to use its cutting edges for purposes other than harvesting. The fact that it does not show substantial damage or use wear does not support this idea, however. Otherwise, it could have been brought by a donkey caravan from the Limestone Plateau together with a load of collected caramel flint sherds, destined for the workshops in Ayn Asil. Because of circumstances unknown to us, the piece was lost at site El-Bueb 16/1. It seems rather unlikely, however, that the flint sherd had already been retouched at the outcrop. It is probable that tabular flint slabs and sherds were roughly trimmed at the outcrops due to transport efficiency, but that the retouching of working edges was accomplished only in the workshops of the oasis. Nevertheless, this case opens up our view to the long neglected aspect of 
266 Heiko Riemer and Karin Kindermann

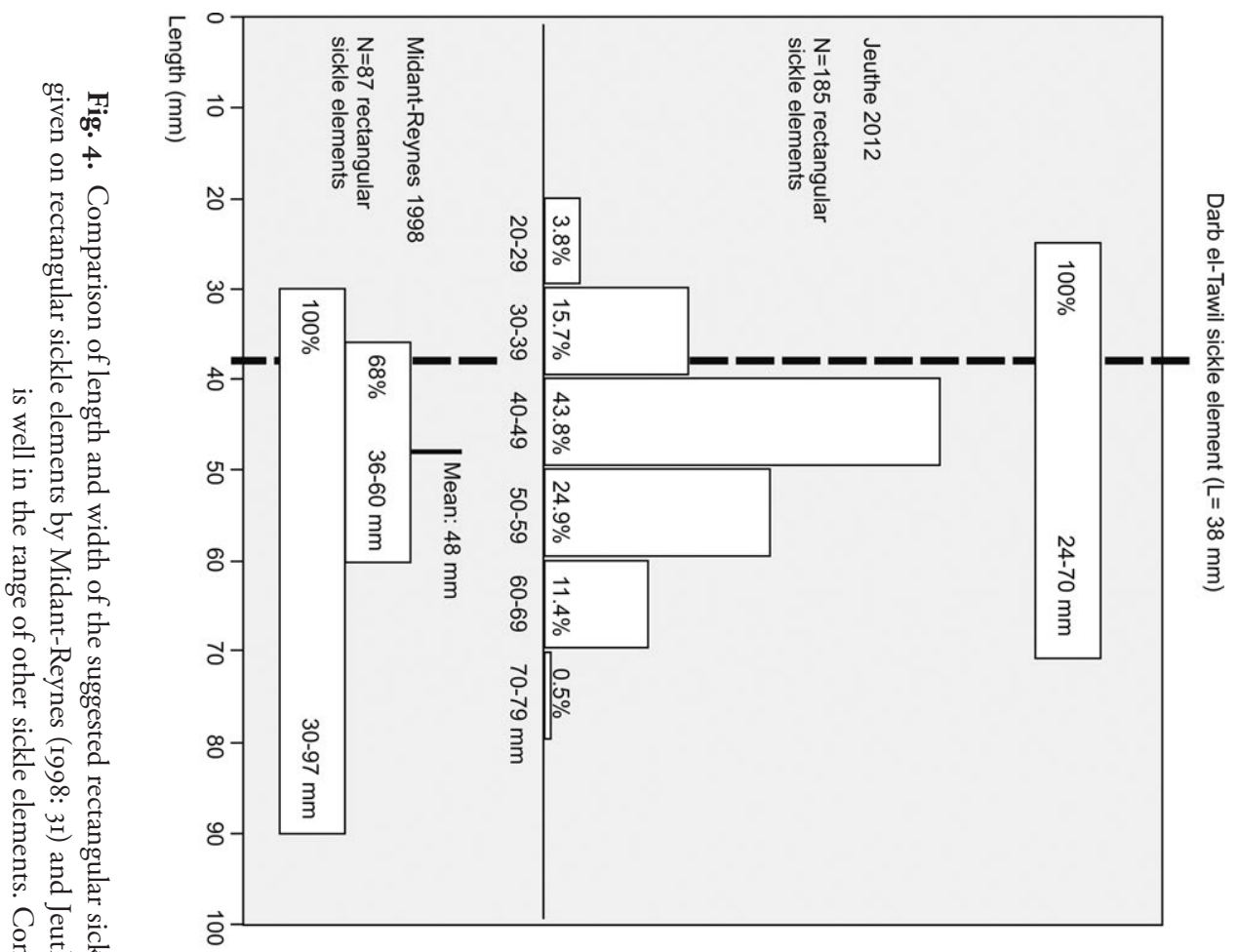

产 융 危

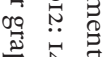

点

.

I

空。

索章

D.

索.

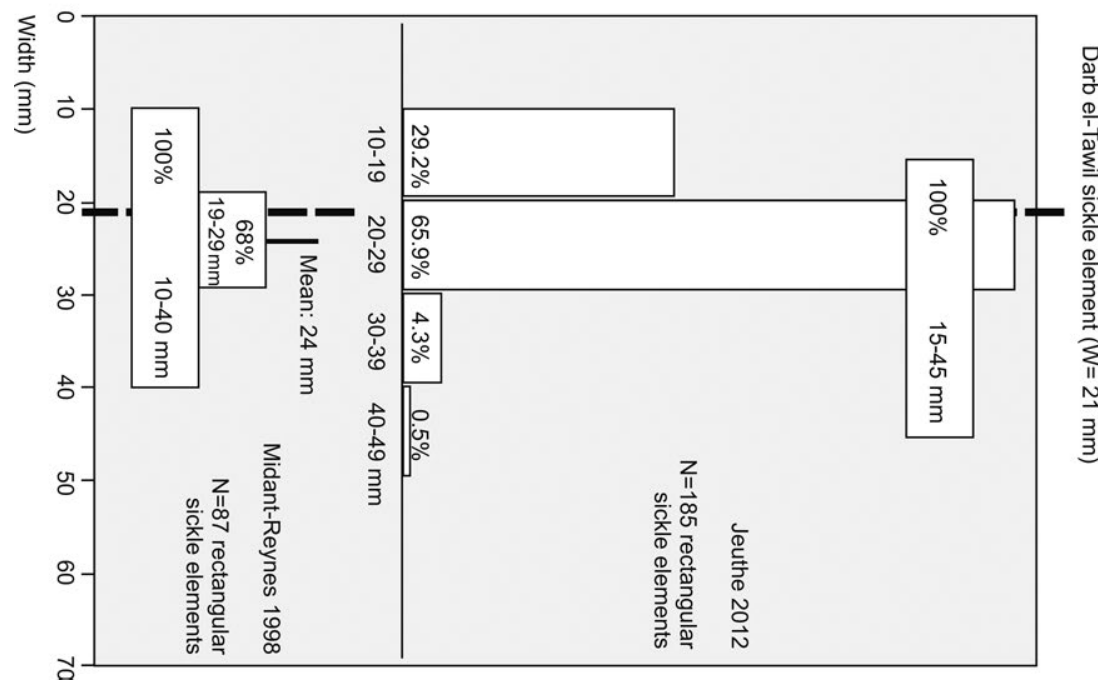


Flints from the Road: on the Significance of two Enigmatic Stone Tools Found along the Darb el-Tawil $\mid 267$

lithic raw material acquisition during the Old Kingdom. It is only during recent years that research on Old Kingdom flint mining in the Eastern Desert has drawn attention to the modes of supply and transport of quarried flints (Briois and Midant-Reynes 20I4; Köhler et al., 20I7), and it is more than likely that high-quality caramel-coloured flint was mined or rather collected on the Egyptian Limestone Plateau.

GUNFLINT (OBJECT ID 172351), ABOUT 27 KM FROM BALAT, NEAR BALAT PASS

\section{Location and context}

The second stone artefact discussed in this paper is an almost rectangular chipped piece of flint (Fig. 2:2). The raw material is a dense semi-translucent greyish brown flint of a type perfectly suited for knapping. This stone artefact was found some $2 \mathrm{~km}$ below the Balat pass (Naqba Balat), the final climb out of the Wadi el-Tawil onto the Egyptian Limestone Plateau (Fig. I). It was discovered just by the main track of the route on the desert surface. No other artefact was found directly associated, nor was any site feature or cluster of artefacts observed on the spot that could indicate a temporary halting place for the caravans. But it is of interest that west of the finding place the route climbs a steep sand ramp which is littered by camel bones and lost objects, among which is a considerable number of sherds from jars, porcelain, and clay pipes dating to the Ottoman period.

The current flint piece is of rectangular shape, but significantly shorter than the sickle element described above for the site El-Bueb 16/1. The continuous slightly convex surface does not show indications of a typical ventral face. It is obviously a thermoclastic sherd (or frost fracture) typical for flint-rich desert surfaces. Such fragments as well as the greyish brown raw material are characteristic for the Limestone Plateau, which the Darb el-Tawil caravan route crosses (Kindermann 20IO). The dorsal surface is completely covered by larger thinning scars. The lateral edges are retouched, one on the ventral face, and the other edge on the dorsal face. The scars of the ventral edge retouch show traces of polish along their ridges.

It appears that this item is not comparable to any of the chipped lithic tool types known in Egypt. Although the raw material is characteristic for the region, and both the facial retouch and the use of thermo-clastic fragments is common for the midHolocene lithic production of late hunter-gatherers between the oases and the Nile Valley, the rectangular shape and relatively small size of the object does not fit with any of the lithic tools of this or other periods.

Flint was of course one of the most important materials for the production of stone artefacts for millennia during pre- and early historic times, but this raw material was also used for specific purposes in modern times too. The use of stone tools survived 
into the modern world, where they could do something cheaply and as effectively as metal tools or even performed tasks metal could not. Stone elements were used in the past, for instance, as insets in wooden threshing sledges (e.g., Anderson 2003; Weiner 20I2c; Anderson and Whittaker 20I4; Whittaker 20I4). They were also used as strike-a-lights (e.g., Stapert and Johansen 1999; Weiner 20I2a), or gunflints (e.g., Weiner $2012 \mathrm{~b}$ ). Finds of the latter group of artefacts would not be surprising on an old trade or caravan route that has been used up to the 20 th century.

\section{Flintlock firearms}

The second half of the I6th century saw the emergence of firearms in which the ignition mechanism (called flintlock) created a spark by means of an inserted gunflint. The widespread use of flintlock rifles, muskets and pistols in the past created a high demand of retouched flint artefacts, so-called gunflints (Germ. Flintensteine, French pierres à fusil, Ital. pietrefocaie or pietre da fucile, Span. piedras de fusil). They replaced wheelock firearms (known from the early i6th century on), in which a spark was created by friction between a denticulated wheel of steel and a piece of pyrite. In the flintlock (Fig. 5), a trigger releases the so-called cock or hammer (Germ. Hahn, French chien), which holds the gunflint, almost always wrapped in a piece of leather or lead. This falls against a piece of steel, named frizzen or battery (Germ. Batterie, French batterie), which produces sparks that ignite a priming charge. This in turn sets off the main charge of gunpowder (Whittacker 2003: 52; Weiner 20I2b: 962; Kolesnik and Holubieva 2018, 132-I33).

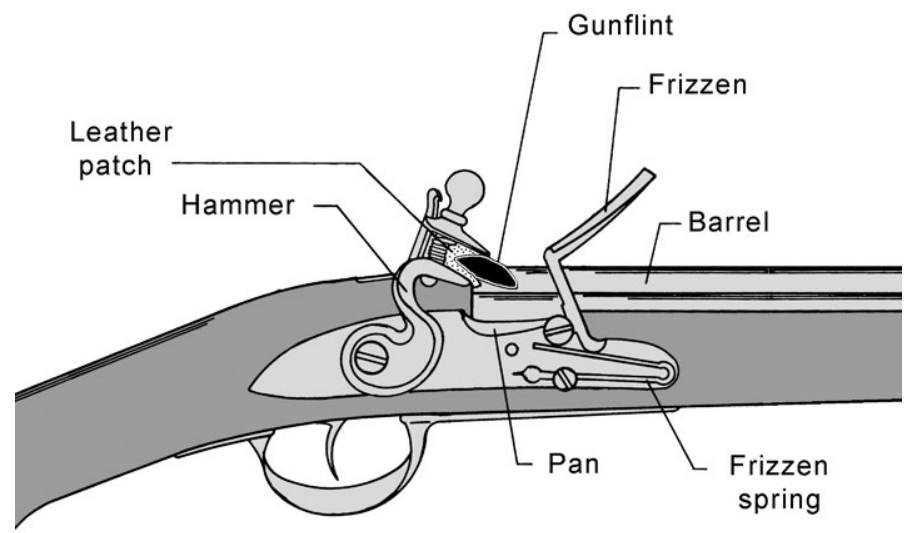

Fig. 5. Elements and operating principle of the firing mechanism of a flintlock musket. Modified after Kenmotsu (1990: 95, Fig. 3). 
The flintlock system quickly became popular, and was known and used in various forms throughout all of Europe and most probably also in North Africa and the Middle East. Flintlock weapons were the major weapon of all European nations from the late I6oos until the early I80os (Whittacker 2003: 52), a period in which also trade on the Darb el-Tawil route was quite active and certainly needed protection from raids and robbery by armed persons. The flintlock firearm was commonly used by the military until the middle of the igth century, when it was replaced by a so-called percussion lock system, a system without gunflints (Weiner 20I2b: 96I). Such a percussion lock gun of the 19th century was accidentally found during an archaeological survey near to the Darb el-Farafra, the direct caravan route between the Nile Valley and the oasis of Farafra starting at about the same point at the Nile Valley as the Darb el-Tawil (Fig. 6). This find indicates that guns were carried by caravan people in the recent past.

\section{Gunflints}

The high demand for gunflints created by the dominance of flintlock arms during the past centuries generated a revival in flint-knapping in several regions in the 16th-17th centuries. This production gained military and thus economic importance and hence, in several European countries of the 16 th-19th centuries, a distinctive flint industry developed. Thus, in regions with suitable flint deposits, specialized gunflint manufactories were established for a mass production. Among the most important centres were those in France and in England (Skertchley 1879: 963-964). French gunflints were generally regarded as the highest quality and were therefore imported to various European countries and also to the French colonies abroad. English gunflints were only used by the English military and in their own colonies. Until the middle of the 19th century, large quantities of gunflints were also produced in other European limestone regions as for example in Belgium, Austria, Denmark, Sweden, Italy, Poland, Albania, Bulgaria, Turkey or Russia (Hahn 1993: 138; Weiner 20I2b: 963-964; Kolesnik and Holubieva 20I8: 132-133). In Egypt, firearms became common with the occupation by the Ottoman Empire, unfortunately only very little is known about gunflints in this part of Northeast Africa. The use of flintlocks and the production of gunflints are indirectly evidenced by Schweinfurth (1885), who mentions the finding of gunflints in the Eastern Desert, but neither is there information about the technical aspects of the production nor of the shape of the final gunflints.

Gunflints resemble a special type of geometric microlith that was used exclusively for the production of sparks. Due to their shape and appearance, some researchers call them "gunflint microlith inserts" or "prismatic gunflints" but a clear morphological typological division does not exist. However, this may probably not be very effective either, since the shape of a gunflint had no real practical meaning as it is always wrapped in the gunlock and could hence vary to some extent in shape and edge trimming, from segment-like (Germ. Hufeisenform, French talon rond) with one striking (leading) 
270 Heiko Riemer and Karin Kindermann
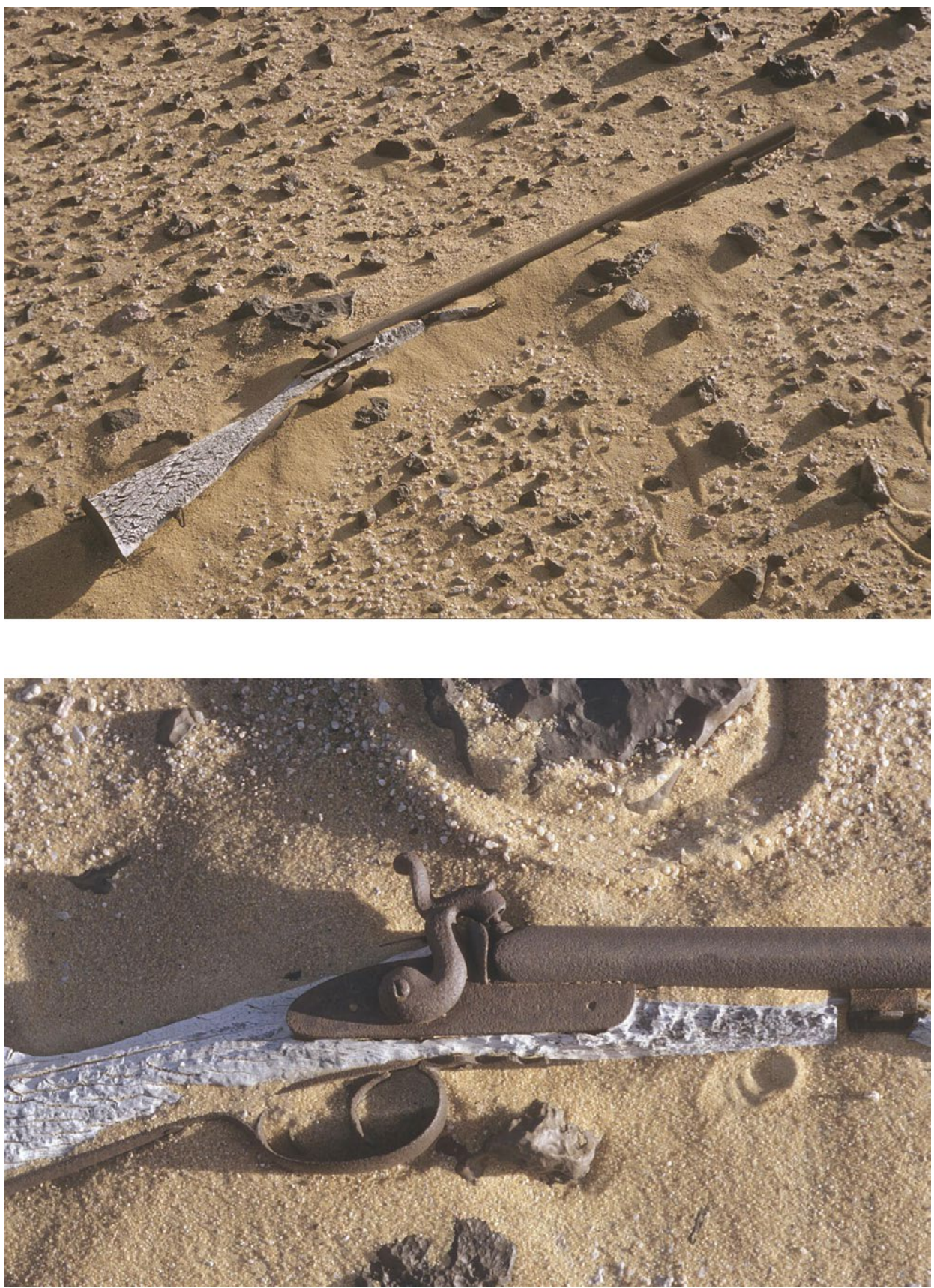

Fig. 6. Find of a percussion lock gun near to the caravan route between the oasis of Farafra and the Nile Valley. Photo: R. Kuper (1993). 

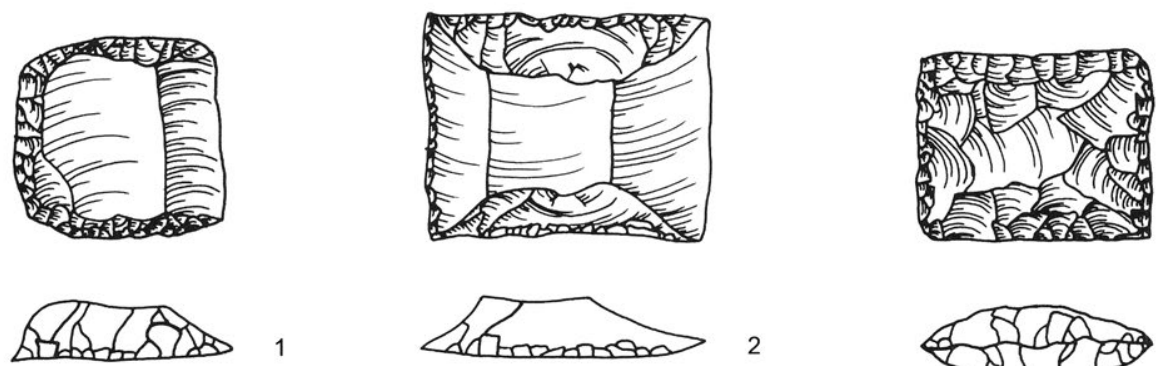

1
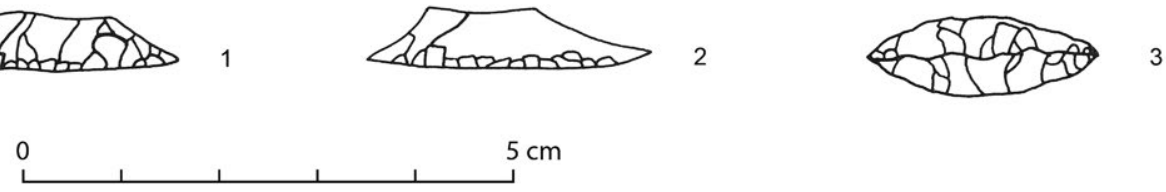

Fig. 7. Typical shapes of gunflint: I - French gunflint from blade, I700s; 2 - British gunflint from blade, I80os; 3 - Native American bifacial gunflint, I6oos. Modified after Whittaker (2003: 53, Fig. 3.22).

edge to sub-square with one or two opposed striking (leading) edges (Weiner 20I2b: 964; Kolesnik and Holubieva 20I8: I32-I33, I40). Generally the lateral edges as well as the leading edge and the heel were beveled, which could be produced by retouching. Often the thin leading edge, as the working-edge of the gunflint, was unmodified but could be strengthened by retouch on the lower face of the edge (Ballin 20I2: II7).

In morphological and technological terms, of importance are only the two main structural parts of a gunflint, the striking (leading) edge and the back or the heel (Fig. 7). The first is more or less straight and mostly sharp, whereas the heel, hidden in the wrap, varied in its morphology (Kolesnik and Holubieva 2018: 132-133).

Gunflints could be knapped out of flakes as well as blades (Weiner 2012b: 964-969), generally these blanks were afterwards broken (knapped) into short sections by the gunflint makers (Skertchly I879; Whittaker 2003: II). Early gunflints were sometimes knapped from the ventral faces of large, thick flakes, which give them two opposed ventral faces (Ballin 2012: II8). After gunflint crafts in the French, English and other centres developed mass production, gunflints were usually made out of regular blades with a range of a rather standardized set of morphological types. But the additional use of flakes and other blank types may have persisted in other regions.

Detailed descriptions of such manufacturing process as well as characteristic features and absolute measurements of gunflints are not easy to find in the literature. A comprehensive study of the English gunflint production of Brandon is published by Skertchly (1879; cf. Lotbiniere 1977; 1984). Regarding the absolute dimensions of a gunflint, research on gunflints from $16 \mathrm{th} / \mathrm{I} 7$ th century of south-eastern Ukraine by Kolesnik and Holubieva indicates that "the sizes of the gunflints were probably 
$272 \mid$ Heiko Riemer and Karin Kindermann

determined by the shape of the gunlocks, and they varied between $24 \mathrm{~mm}$ and $37 \mathrm{~mm}$ in length for this type with approximately the same variation in width" (Kolesnik and Holubieva 20I8: I40).

\section{Gunflints from the road?}

The flint object (Fig. 2:2) from the Balat pass on the Darb el-Tawil caravan route described above can be interpreted in the light of morphology and size of the gunflints discussed above as falling into the same range. The nature of its find spot would also correspond to the archaeological and chronological setting one would expect for artefacts related to flintlock weapons. It was a single surface find lying in the direct context of the Darb el-Tawil (one of the major long-distance trade routes of Northeast Africa) and found with ceramics dating to the Medieval to Ottoman periods. The interpretation of the stone artefact as a gunflint would fit the wider context; given its general shape and that it does not match any other type of flint tool known from the Egyptian deserts.

Although this piece with its rectangular shape seems comparable to the rectangular sickle flint described above, it appears substantially different, due to its shortness and greater thickness, as well as its facial retouch. A bevel, as described for gunflints in general, seems also to have been consciously created along the edges of this piece by retouch. The form of the longitudinal edges of the artefact could be considered as the leading edge and a heel of a gunflint. Likewise the lateral retouch on the ventral face of the artefact would support the gunflint interpretation, which could be a strengthening retouch on the lower face of the leading edge as described before. Whether the blank used for this stone artefact may have originally been a "janus-like" piece is difficult to decide. In addition, it seems possible that the scars and negatives on the "ventral" face as well as the little notch on the lateral edge (heel?) of the piece may be due to its use as a gunflint.

\section{CONCLUSION}

Lithic studies are usually the domain of archaeologists studying Pleistocene and Holocene hunter-gatherers as well as the early Neolithic, and have more recently also appeared in research on pastoral nomadic contexts and early state-based societies. In general, the importance of lithic artefacts and technology as a research subject decreases in the study of later periods, virtually vanishing in more recent history, even though flints have been used for specific purposes up to modern times. The pre-industrial production of gunflints has been described in books of the igth and early 2oth century, but there has been little attention payed by archaeologists to the role such objects have played in history. The current study should serve to encourage lithic studies of more 
recent societies and draws attention to the fact that lithic objects may occur unexpectedly out of their usual context, such as on the line of a caravan route, and that their function in trade and transport has so far been barely explored.

\section{ACKNOWLEDGEMENTS}

The Darb el-Tawil survey is funded by Deutsche Forschungsgemeinschaft (DFG), project no. 291189480 (H. Riemer).

\section{REFERENCES}

Anderson, P. C. 2003. Observations on the threshing sledge and its products in ancient and present-day Mesopotamia. In P. C. Anderson, L. S. Cummings, T. K. Schippers and B. Simonel (eds), Le traitement des récoltes: Un regard sur la diversité, du Néolithique au present, 417-438. Antibes.

Anderson, P. C. and Whittaker, J. C. 20I4. Blades, sickles, threshing sledges and experimental archaeology in northern Mesopotamia. In A. van Gijn, J. C. Whittaker and P. C. Anderson (eds), Exploring and Explaining Diversity in Agricultural Technology, I6I-168. Oxford.

Ballin, T. B. 20I2. 'State of the art' of British gunflint research, with special focus on the early gunflint workshop at Dun Eistean, Lewis. Post-Medieval Archaeology 46(I): II6-I42.

Briois, F. and Midant-Reynes, B. 20I4. Sur les traces de Georg August Schweinfurth. Les sites d'exploitation du silex d'époque pharaonique dans le massif du Galâlâ nord (desert Oriental). Bulletin de l'Institut français d'archéologie orientale $\mathrm{II} 4(\mathrm{I}):$ 73-98.

Bubenzer, O., Bolten A. and Riemer, H. 20I8. In search of the optimal path to cross the desert: Geoarchaeology traces old Trans-Saharan Routes. In C. Siart, M. Forbriger and O. Bubenzer (eds), Digital geoarchaeology. New techniques for interdisciplinary human-environmental research, 139-I48. Berlin.

Driscoll, K., Alcaina, J., Égüez, N., Mangado, X., Fullola, J.-M. and Tejero, J.-M. 20ı6. Trampled under foot: A quartz and chert human trampling experiment at the Cova del Parco rock shelter, Spain. Quaternary International 424: 130-I42.

Giddy, L. L., 1987. Egyptian oases. Bahariya, Dakhla, Farafra and Kharga during Pharaonic times. Warminster.

Hahn, J. 1993. Erkennen und Bestimmen von Stein- und Knochenartefakten. Einführung in die Artefaktmorphologie. Tübingen.

Hope, C. A. and Pettman, A. J. 20I2. Egyptian Connections with Dakhleh Oasis in the Early Dynastic Period to Dynasty IV: new data from Mut al-Kharab. In R. Bagnall, P. Davoli and C. A. Hope (eds), The Oasis Papers 6: Proceedings of the Sixth International Conference of the Dakhleh Oasis project, I47-165. Exeter. Dakhleh Oasis project: Monograph I5.

Jeuthe, C. 20I2. Balat X. Ein Werkstattkomplex im Palast der I. Zwischenzeit in Ayn Asil. Cairo, Fouilles de l'IFAO 7I.

Jeuthe, C., Le Provost, V. and Soukiassian, G. 2013. Ayn Asil, palais des gouverneurs du règne de Pépy II. État des recherches sur la partie sud. Bulletin de l'Institut français d'archéologie orientale II3: 203-238.

Kaper, O. E. and Willems, H. 2002. Policing the Desert: Old Kingdom Activity around Dakhleh Oasis. In R. Friedman (ed.), Egypt and Nubia: Gifts of the Desert, 79-94. London. 
274 Heiko Riemer and Karin Kindermann

Kenmotsu, N. 1990. Gunflints: A Study. Historical Archaeology 24(2): 92-I24.

Kindermann, K. 20Iо. Djara: Zur mittelholozänen Besiedlungsgeschichte zwischen Niltal und Oasen (AbuMuharik-Plateau, Ägypten). Cologne.

Kleindienst, M. R., Churcher, C. S., McDonald, M. M. A. and Schwarcz, H. P. 1999. Geography, Geology, Geochronology and Geoarchaeology of the Dakhleh Oasis Region: An Interim Report. In C. S. Churcher and A. J. Mills (eds), Reports from the Survey of the Dakhleh Oasis 1977-1987, I-54. Oxford.

Kobusiewicz, M. 20I5. The Production, Use and Importance of Flint Tools in the Archaic Period and the Old Kingdom of Egypt. Oxford.

Köhler, E. C., Hart, E. and Klaunzer, M. 20I7. Wadi el-Sheikh: A new archaeological investigation of ancient Egyptian chert mines. PLoSOne I2(2): e0170840. https://doi.org/10.1371/journal.pone.0170840

Kolesnik, A. and Holubieva, I. 20I8. Gunflints from I6th/I7th century archaeological assemblages from the central part of the Severskiy Donets River (south-eastern Ukraine). Archäologische Informationen 4I: $\mathrm{I} 3 \mathrm{I}-\mathrm{I} 48$.

Lotbiniere, S. de 1977. The Story of the English Gunflint Some Theories and Queries. The Journal of the Arms \& Armour Society 9(I): 40-53.

Lotbiniere, S. de 1984. Gunflint recognition. International Journal of Nautical Archaeology and Underwater Exploration 13(3): 206-209.

McDonald, M. M. A. 2000. Appendix: The Chipped Stone from Nephthys Hill, Locality 386. In R. Friedman (ed.), Egypt and Nubia: Gifts of the Desert, 91-92. London.

Midant-Reynes, B. 1998. Le silex de Ayn-Asīl, Oasis de Dakhla - Balat. Cairo.

Moritz, M. 1900. Excursion aux oasis du désert libyque. Bulletin de la Société Khédiviale de Géographie 5(8): 429-475.

Pettman, A. J. 20I2. The Date and the Occupation of 'Ain el-Gazzareen based on Ceramic Evidence. In R. Bagnall, P. Davoli and C. A. Hope (eds), The Oasis Papers 6: Proceedings of the Sixth International Conference of the Dakhleh Oasis project, I8I-208. Exeter, Dakhleh Oasis project: Monograph I5.

Riemer, H. 20II. El Kharafish: The archaeology of Sheikh Muftah pastoral nomads in the desert around Dakhla Oasis (Egypt). Cologne.

Schweinfurth, G. 1885. Kiesel-Nuclei aus der arabischen Wüste. Zeitschrift für Ethnologie 17: 128-134.

Skertchly, S. B. J. I879. On the manufacture of gun-fints, the methods of excavating for flint, the age of paleolithic man, and the connexion between neolithic art and the gun-fint trade. London.

Stapert, D. and Johansen, L. 1999. Flint and pyrite: making fire in the Stone Age. Antiquity 73: 765-777.

Valloggia, M. 1986. Balat I. Le Mastaba de Medou-Nefer, Fascicule II: Planches. Cairo.

Weiner, J. 20I2a. Feuerschlagsteine und Feuerzeugung. In H. Floss (ed.), Steinartefakte vom Altpaläolithikum bis in die Neuzeit, 943-960. Tübingen.

Weiner, J. 20I2b. Flintensteine. In H. Floss (ed.), Steinartefakte vom Altpaläolithikum bis in die Neuzeit, 96I-972. Tübingen.

Weiner, J. 20I2c. Dreschschlitten. In H. Floss (ed.), Steinartefakte vom Altpaläolithikum bis in die Neuzeit, 973-980. Tübingen.

Whittaker, J. C. 2003. Flintknapping. Making and Understanding Stone Tools. Austin.

Whittaker, J. C. 20I4. The manufacture and use of threshing sledges. In A. van Gijn, J. C. Whittaker and P. C. Anderson (eds), Exploring and Explaining Diversity in Agricultural Technology, I4I-I44, I84-I89. Oxford. 